\title{
Pengaruh Wireless Security Protocol Pada Throughput Jaringan Wireless 802.11ax
}

\author{
Vian Ardiyansyah Saputro', Suwanto Raharjo², Eko Pramono ${ }^{3}$ \\ ${ }^{13}$ Universitas Amikom Yogyakarta/Magister Teknik Informatika \\ e-mail: ${ }^{1}$ vian.students@ amikom.ac.id, ${ }^{3}$ eko.p@amikom.ac.id \\ ${ }^{2}$ IST AKPRIND Yogyakarta/Informatika \\ e-mail:wa2n@akprind.ac.id
}

\begin{abstract}
Abstrak - Standar dan regulasi untuk teknologi jaringan wireless telah mengalami beberapa perubahan, terbaru IEEE merilis standar baru untuk memperbarui standar jaringan wireless sebelumnya dengan nama IEEE 802.11ax atau yang lebih dikenal dengan Wi-Fi 6. Tidak seperti halnya pada jaringan kabel, di dalam penggunaan jaringan wireless memiliki berbagai permasalahan, salah satunya adalah masalah kerentanan keamanan hal ini dikarenakan penggunaan frekuensi yang sifatnya lebih terbuka dibandingkan dengan menggunakan jaringan berbasis kabel, dengan adanya kerentanan keamanan jaringan wireless tersebut, salah satu cara yang dapat dilakukan untuk mengamankan jaringan wireless adalah dengan mengaktifkan wireless security protocol di perangkat access point yang digunakan, namun cara ini dapat menyebabkan menurunnya kualitas throughput yang di dapatkan oleh pengguna jaringan wireless. Penelitian ini bertujuan untuk membandingkan pengaruh penggunaan wireless security protocol mode WPA2-AES dan WPA3- SAE terhadap throughput jaringan wireless 802.11ax. Hasil penelitian menunjukan bahwa penggunaan wireles security protocol berdampak pada penurunan kualitas throughput jaringan wireless 802.11ax, dimana pada channel width $20 \mathrm{Mhz}$ mengalami penurunan hingga $0.9 \%$ baik untuk WPA2-AES maupun WPA3-SAE dan di channel width $40 \mathrm{Mhz}$ mengalami penurunan hingga $1.79 \%$ untuk WPA2-AES namun untuk WPA3-SAE kualitas throughput dapat terjaga serta di channel width $80 \mathrm{Mhz}$ mengalami penurunan hingga $1.48 \%$ untuk WPA2-AES dan 9.50\% untuk WPA3-SAE.
\end{abstract}

Kata Kunci: 802.11ax, throughput, channel width, wpa2-aes, wpa3-sae

Abstract - Standards and regulations for wireless network technology have undergone several changes, the latest IEEE released a new standard to update the previous wireless network standard with the name IEEE 802.11ax or better known as Wi-Fi 6. Unlike wired networks, in the use of wireless networks has various problems, one of which is the problem of security vulnerabilities this is due to the use of frequencies that are more open than using a cable-based network, with the security vulnerability of the wireless network, one way that can be done to secure a wireless network is to activate the wireless security protocol. on the access point device used, but this method can cause a decrease in the quality of throughput that is obtained by wireless network users. This study aims to compare the effect of using WPA2-AES and WPA3-SAE wireless security protocol modes on 802.11ax wireless network throughput. The results show that the use of wireless security protocols has an impact on the quality of 802.11ax wireless network throughput, where the $20 \mathrm{Mhz}$ channel width has decreased up to 0.9\% for both WPA2-AES and WPA3-SAE and the $40 \mathrm{Mhz}$ channel width has decreased up to $1.79 \%$ for WPA2-AES but for WPA3-SAE the throughput quality can be maintained and at $80 \mathrm{Mhz}$ channel width it has decreased by $1.48 \%$ for WPA2-AES and $9.50 \%$ for WPA3-SAE.

Keywords: 802.11ax, throughput, channel width, wpa2-aes, wpa3-sae

\section{PENDAHULUAN}

Dalam perkembangan jaringan wireless 802.11, standar dan regulasi untuk teknologi jaringan wireless telah mengalami beberapa perubahan, terbaru IEEE merilis standar baru untuk memperbarui standar jaringan wireless sebelumnya dengan nama IEEE 802.11ax atau yang lebih dikenal 
dengan Wi-Fi 6. Seperti kebanyakan teknologi wireless baru lainnya, teknologi wireless baru ini menawarkan data rate hingga 9,6 Gbps dengan menggunakan channel width $160 \mathrm{Mhz}$, dan bekerja di frekuensi 2,4 Ghz dan $5 \mathrm{Ghz}$, kemudian adanya fitur protokol keamanan baru WPA3 - SAE dimana di dalam protokol keamanan ini menambahkan beberapa fitur baru yang diyakini dapat menyederhanakan keamanan, autentikasi yang lebih kuat, dan meningkatkan keamanan lalu lintas data yang melewati di jaringan tersebut.

Tidak seperti halnya pada jaringan kabel, di dalam penggunaan jaringan wireless memiliki berbagai permasalahan, salah satunya adalah masalah kerentanan keamanan hal ini dikarenakan penggunaan frekuensi yang sifatnya lebih terbuka dibandingkan dengan menggunakan jaringan berbasis kabel (Riyan Feraldi., 2019). Secara garis besar, kerentanan keamanan pada jaringan wireless terdiri atas empat layer di mana keempat lapis (layer) tersebut sebenarnya merupakan proses dari terjadinya komunikasi data pada media jaringan wireless. Keempat layer tersebut adalah physical layer, network layer, user layer dan application layer (Supriyanto, 2006).

Dengan adanya kerentanan keamanan jaringan wireless seperti diatas, salah satu cara yang dapat dilakukan untuk mengamankan jaringan wireless adalah dengan mengaktifkan wireless security protocol di perangkat access point yang digunakan, namun cara ini dapat menyebabkan menurunnya kualitas throughput yang di dapatkan oleh pengguna jaringan wireless (Mohammed, 2016).

Berdasarkan penelitian yang dilakukan oleh (Tsetse et al., 2018), mengenai dampak penggunaan wireless security protocol pada jaringan wireless IEEE 802.11 ac dengan menggunakan tiga mode keamanan yang berbeda yaitu mode no security, personal security, dan enterprise security. Hasilnya menunjukkan bahwa kualitas throughput mengalami penurunan berkisar antara $1,6 \%$ hingga $8,2 \%$ berdasarkan penggunaan pada protocol transport (TCP / UDP) dan IP Address (IPV4 / IPv6). Namun pada penelitian yang telah dilakukan hanya dengan menggunakan parameter keamanan mode WPA2 / AES dan server RADIUS. Selanjutnya di dalam penelitian yang dilakukan oleh (Kolahi \& Almatrook, 2017) mengenai dampak penggunaan wireless security protocol dengan menggunakan mode WPA2 pada jaringan wireless IEEE 802.11ac dengan skenario percobaan client server. Hasil penelitian menunjukkan bahwa penurunan kualitas throughput berkisar antara 10,22\% hingga 18,07\% berdasarkan penggunaan pada transport protokol (TCP / UDP) dan IP Address (IPV4 / IPv6). Namun di dalam penelitian tersebut hanya menggunakan parameter wireless security protocol dengan mode WEP dan WPA.

Selanjutnya pada penelitian mengenai fitur kemanan baru WPA3 yang dilakukan oleh (Kohlios \&
Hayajneh, 2018), mode keamanan WPA3 menawarkan skema baru yang lebih baik bila dibandingkan dengan mode keamanan WPA2, seperti adanya perbaikan masalah re-authentication, off-line dictionary attacks dan the KRACK vulnerability. Dan adanya fitur protected management frame (PMF) yang dapat memberikan pencegahan terhadap serangan DoS (Denial of Service) di jaringan wireless (Kwon \& Choi, 2021). Di dalam metode password authenticated key exchange, WPA3 menggunakan protokol SAE (Simultaneous Authentication of Equals) yang dirancang untuk menggantikan autentikasi WPA2 PSK dan mendukung autentikasi P2P (Peer to Peer) (Sun, 2019).

Sehingga berdasarkan literatur penelitian tersebut maka perlu dilakukan penelitian dengan menggunakan wireless security protocol mode WPA2 - AES dan mode WPA3 - SAE sebagai mode terbaru di dalam keamanan jaringan wireless dan juga penggunaan variasi channel width $20 \mathrm{Mhz}, 40$ Mhz dan 80 Mhz.

Tujuan dari penelitian ini adalah untuk membandingkan pengaruh penggunaan wireless security protocol mode WPA2-AES dan WPA3SAE terhadap throughput jaringan wireless 802.11ax yang dapat menghasilkan kualitas throughput tinggi untuk penggunaan di channel width $20 \mathrm{Mhz}, 40 \mathrm{Mhz}$ dan $80 \mathrm{Mhz}$. Metode penelitian yang dilakukan adalah dengan mengacu pada penelitian yang telah dilakukan oleh (Mohammed, 2016), sehingga nantinya penggunaan wireless security protocol lebih maksimal dan menjadi tolak ukur kinerja jaringan di lingkungan wireless IEEE 802.11ax.

Untuk penelitian yang kami lakukan dapat memberikan kontribusi ilmu pengetahuan mengenai bagaimana penggunaan wireless security protocol memberikan pengaruh terhadap throughput jaringan wireless IEEE 802.11ax, hal ini dikarenakan beberapa penelitian lain yang sudah dilakukan, sebagian besar penelitian dilakukan dengan standar IEEE 802.11 sebelumnya.

\section{METODOLOGI PENELITIAN}

Metode penelitian yang digunakan adalah eksperimental yaitu membuat suatu eksperimen untuk mendapatkan hasil dan selanjutnya hasil tersebut dianalisis. Di dalam penelitian ini terbagi menjadi 4 tahapan penelitian seperti yang terlihat di dalam gambar 1.

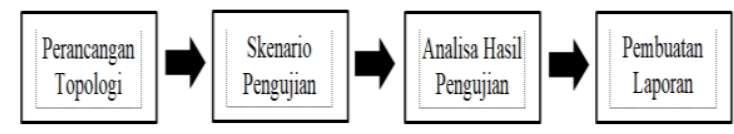

Sumber : (Saputro et al., 2021)

Gambar 1. Tahapan penelitian 
Gambar 1 adalah tahapan penelitian, berikut adah penjelasan setiap tahapan yang ada di dalam gambar tersebut :

1. Perancangan Topologi

Di dalam perancangan topologi, skenario topologi jaringan menggunakan topologi client server dimana di dalam percobaan ini akan menggunakan PC client yang terinstal sistem operasi Windows 10 Pro dan terpasang wireless card TPLink AX3000 yang nantinya terhubung ke jaringan wireless menggunakan access point indoor TPLink Archer AX1500, sedangkan untuk PC server terinstal sistem operasi Windows Server 2016 Standard (GUI) yang terhubung ke access point menggunakan kabel UTP Cat6. Di dalam penelitian ini, akan dilakukan dengan menggunakan frekuensi $5 \mathrm{Ghz}$ yang dapat menghasilkan kualitas throughput lebih tinggi dibandingkan dengan penggunaan frekuensi 2.4 $\mathrm{GHz}$ (Lepaja et al., 2018) serta frekuensi $5 \mathrm{Ghz}$ dapat menjadi alternatif digunakan di dalam jaringan wireless untuk menunjang pekerjaan perkantoran dengan aktifitas seperti browsing internet, download, pertukaran data, dan video conference (Bakri et al., n.d.), sehingga nantinya di dapatkan hasil kualitas troughput maksimal jaringan wireless IEEE 802.11 ax. Jarak antara PC client dengan access point indoor adalah 1 meter hal ini untuk mempertahankan kekuatan sinyal yang optimal seperti ditunjukan di dalam gambar 2 .

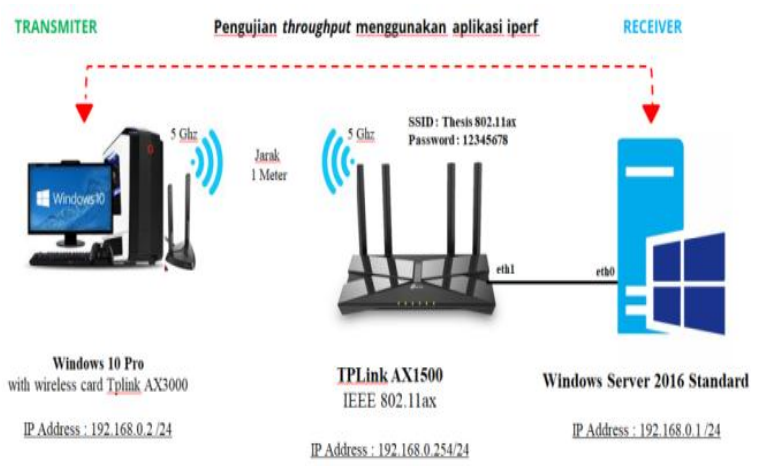

Sumber : (Saputro et al., 2021)

Gambar 2. Skenario Topologi Pengujian

Di dalam perancangan topologi pengujian menggunakan IP address versi 4 untuk setiap perangkat yang terhubung di dalam skenario jaringan diatas, dimana PC server menggunakan IP Address 192.168.0.1/24, dan untuk PC client menggunakan IP Address 192.168.0.2/24 serta access Point TPLink AX1500 yang berfungsi sebagai penghubung antara PC server dan PC client menggunakan IP Address 192.168.0.254/24. Selanjutnya, berbagai parameter pengujian diterapkan meliputi penggunaan wireless security protocol, dan jenis paket TCP Window Size. Parameter yang digunakan untuk pengujian dirangkum dalam tabel 1.
Tabel 1. Parameter Pengujian

\begin{tabular}{|c|c|}
\hline \multicolumn{2}{|c|}{ Parameter } \\
\hline $\begin{array}{c}\text { Security } \\
\text { Protocols }\end{array}$ & $\begin{array}{c}\text { Open Security, WPA2 - } \\
\text { AES, WPA3 - SAE }\end{array}$ \\
\hline $\begin{array}{c}\text { Network } \\
\text { Traffic }\end{array}$ & TCP \\
\hline Window Size & $\begin{array}{c}128 \mathrm{~KB}, 384 \mathrm{~KB}, 640 \mathrm{~KB}, \\
1152 \mathrm{~KB}, 1408 \mathrm{~KB}\end{array}$ \\
\hline
\end{tabular}

Sumber : (Saputro et al., 2021)

Untuk mendapatkan hasil yang maksimal di dalam penelitian ini, maka kami mempertimbangkan penggunaan perangkat keras untuk PC Server, PC Client, Access Point dan Wireless Card Adapter dengan spesifikasi sebagai berikut :

Tabel 2. Spesifikasi Perangkat Keras

\begin{tabular}{|c|c|c|}
\hline $\begin{array}{l}\text { Perangkat } \\
\text { Keras }\end{array}$ & Fungsi & Spesifikasi \\
\hline TP-Link & & Wi-Fi 6 (802.11ax) \\
\hline Archer AX10 & & with $\mathrm{Up}$ to 1501 \\
\hline AX1500 & Wireless & $\mathrm{Mb} / \mathrm{s}, 2.4 \mathrm{GHz} / 5$ \\
\hline Wireless & Access & GHz (Dual-Band), \\
\hline Dual-Band & Point & Support Gigabit LAN \\
\hline Gigabit & & Ports, Support WPA3 \\
\hline Router & & SAE. \\
\hline $\begin{array}{c}\text { TP- } \\
\text { LinkAX3000 }\end{array}$ & $\begin{array}{l}\text { Wireless } \\
\text { Card }\end{array}$ & $\begin{array}{l}\text { WiFi } 6 \text { PCIe Card, } \\
\mathrm{Up} \text { to } 2400 \mathrm{Mbps} \text {, }\end{array}$ \\
\hline WiFi Card & Adapter & $\begin{array}{l}\text { 802.11AX Dual Band } \\
\text { Wireless. }\end{array}$ \\
\hline \multirow{3}{*}{ Server } & \multirow{3}{*}{$\begin{array}{c}P C \\
\text { Server }\end{array}$} & $\begin{array}{l}\text { Intel Xeon E-2224G } \\
\text { 3.5GHz, 8GB DDR4, } \\
\text { 1TB SATA 3.5in, D- }\end{array}$ \\
\hline & & LINK Gigabit \\
\hline & & $\begin{array}{l}\text { Ethernet Adapter } \\
\text { DGE-560T. }\end{array}$ \\
\hline & & Intel Core i9-10900 \\
\hline \multirow{2}{*}{ Client } & $P C$ & 2.8Ghz, DDR4 32 \\
\hline & Client & $\begin{array}{l}\text { GB ( Single Channel } \\
\text { ), SSD } 128 \text { GB }\end{array}$ \\
\hline
\end{tabular}

Sumber : (Saputro et al., 2021)

Penggunaan aplikasi iperf yang terinstal di PC client sebagai transmitter dan di PC server sebagai receiver berfungsi untuk menguji throughput yang dihasilkan oleh jaringan wireless 802.11ax. Dimana perintah untuk menjalankan aplikasi iperf menggunakan command prompt Microsoft Windows, berikut perintah konfigurasi yang digunakan : 


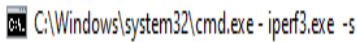
$-\square X$

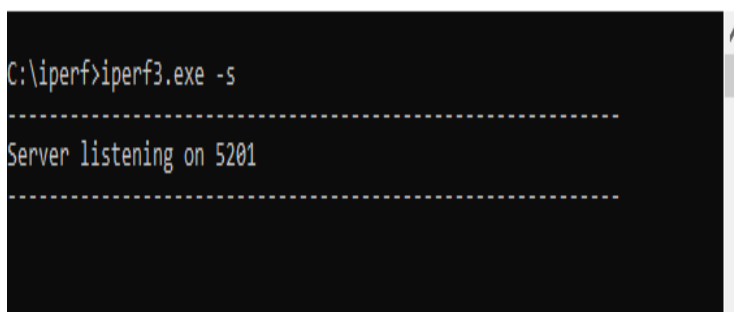

Sumber : (Saputro et al., 2021)

Gambar 3. Perintah iperf untuk PC server yang bertindak sebagai receiver

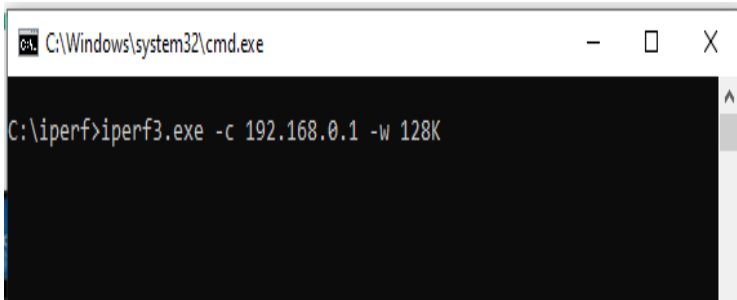

Sumber : (Saputro et al., 2021)

Gambar 4. Perintah iperf untuk PC client yang bertindak sebagai transmitter

\section{Skenario Pengujian}

Penggunaan skenario pengujian di dalam penelitian ini bertujuan untuk mendapatkan nilai throughput tertinggi dari penggunaan No security, WPA2-AES dan WPA3-SAE dengan variasi penggunaan channel width $20 \mathrm{Mhz}, 40 \mathrm{Mhz}$ dan $80 \mathrm{Mhz}$. Konseptual skenario pengujian terlihat di kerangka penelitian di dalam gambar 5 .

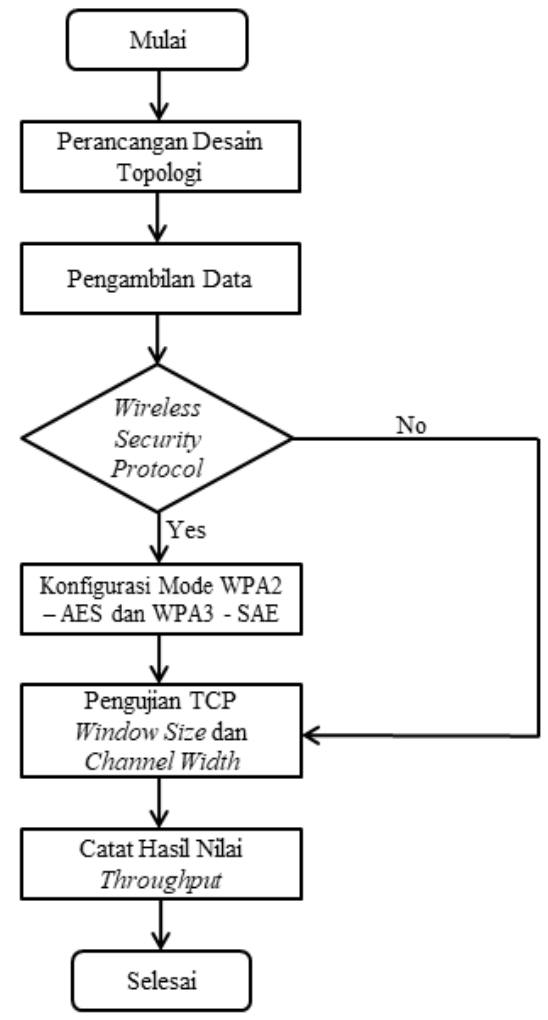

Sumber : (Saputro et al., 2021)

Gambar 5. Kerangka Penelitian
Gambar 5 merupakan kerangka konseptual penelitian yang dilakukan peneliti pada penelitian ini. Berikut penjelasan dari setiap langkah yang dilakukan:

a. Perancangan Topologi : Melakukan perancangan desain topologi untuk penelitian ini dengan tujuan untuk mendapatkan hasil pengujian sesuai dengan tujuan penelitian.

b. Pengambilan Data Skenario Pertama: Melakukan pengambilan data dimana di dalam skenario pertama ini access point menggunakan channel width $20 \mathrm{Mhz}$ dan wireless security protocol No Security, WPA2-AES dan WPA3-SAE. selanjutnya pengujian menggunakan aplikasi iperf dengan mengirimkan paket data berupa paket TCP Window Size dengan ukuran 128KB, $384 \mathrm{~KB}, 640 \mathrm{~KB}, 1152 \mathrm{~KB}$, dan $1408 \mathrm{~KB}$ dari PC client ke PC Server yang terhubung menggunakan access point. Percobaan pengiriman paket data dari PC client menuju PC server melalui jaringan wireless akan dilakukan sebanyak 10 kali dimana setiap pengujian sebanyak 10 detik.

c. Pengambilan Data Skenario Kedua: Melakukan pengambilan data dimana di dalam skenario kedua ini access point menggunakan channel width $40 \mathrm{Mhz}$ dan penggunaan wireless security protocols No Security, WPA2-AES dan WPA3SAE. selanjutnya pengujian menggunakan aplikasi iperf dengan mengirimkan paket data berupa paket TCP Window Size dengan ukuran $128 \mathrm{~KB}, 384 \mathrm{~KB}, 640 \mathrm{~KB}, 1152 \mathrm{~KB}$, dan $1408 \mathrm{~KB}$ dari PC client ke PC Server yang terhubung menggunakan access point. Percobaan pengiriman paket data dari PC client menuju PC server melalui jaringan wireless akan dilakukan sebanyak 10 kali dimana setiap pengujian sebanyak 10 detik.

d. Pengambilan Data Skenario Ketiga: Melakukan pengambilan data dimana di dalam skenario kedua ini access point menggunakan channel width $80 \mathrm{Mhz}$ dan penggunaan wireless security protocols No Security, WPA2-AES dan WPA3SAE. selanjutnya pengujian menggunakan aplikasi iperf dengan mengirimkan paket data berupa paket TCP Window Size dengan ukuran $128 \mathrm{~KB}, 384 \mathrm{~KB}, 640 \mathrm{~KB}, 1152 \mathrm{~KB}$, dan $1408 \mathrm{~KB}$ dari PC client ke PC Server yang terhubung menggunakan access point. Percobaan pengiriman paket data dari PC client menuju PC server melalui jaringan wireless akan dilakukan sebanyak 10 kali dimana setiap pengujian sebanyak 10 detik.

3. Analisa Hasil Pengujian

Analisa hasil pengujian dilakukan untuk mengetahui nilai throughput yang dihasilkan terhadap pengaruh penggunaan wireless security protocol. Hasil pengujian disajikan ke dalam bentuk grafik line 
untuk melihat naik dan turunnya data hasil pengujian yang telah didapatkan.

4. Pembuatan Laporan

Pembuatan laporan bertujuan untuk merangkum semua hal yang berkaitan dengan penelitian ini seperti studi literatur yang digunakan, metode penelitian yang digunakan, skenario perancangan desain jaringan, skenario pengujian, hasil dan pembahasan pengujian.

\section{HASIL DAN PEMBAHASAN}

Pengujian ini dilakukan untuk mengetahui nilai throughput yang dihasilkan dengan variasi pengujian dengan mengirimkan paket TCP Window Size ukuran $128 \mathrm{~KB}, 384 \mathrm{~KB}, 640 \mathrm{~KB}, 1152 \mathrm{~KB}$, dan 1408 KB dari PC Client menuju PC Server yang terhubung dengan Access Point. Dimana terdapat 3 skenario penggunaan wireless security protocol yaitu Access Point menggunakan mode open security, WPA2-AES dan WPA3-SAE.

Berikut hasil dan pembahasan dari pengujian yang telah dilakukan :

1. Perbandingan Penggunaan Wireless Security Protocol Untuk Channel Width $20 \mathrm{Mhz}$

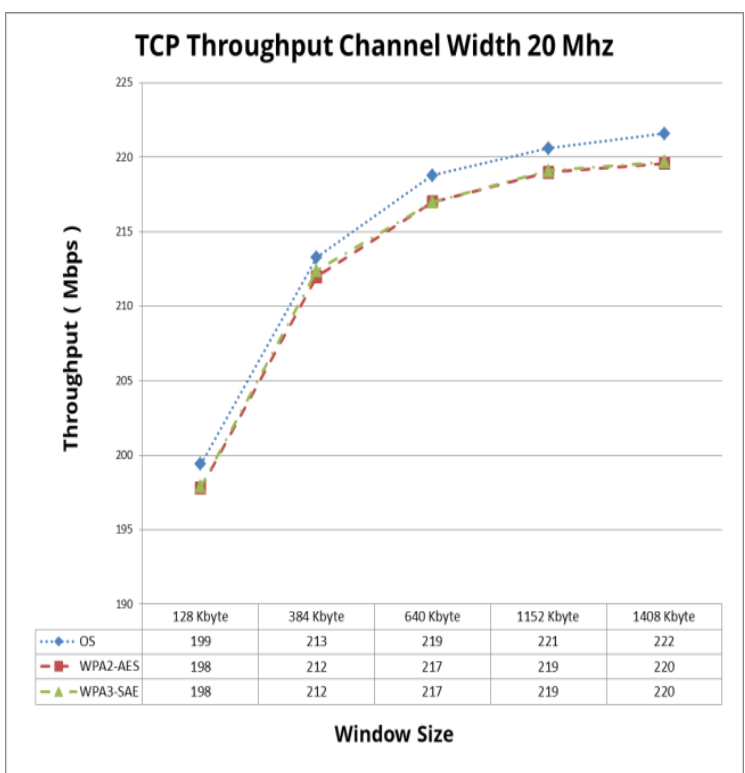

Sumber : (Saputro et al., 2021)

Gambar 6. Grafik Perbandingan Throughput untuk Channel Width $20 \mathrm{Mhz}$

Berdasarkan gambar 6, menunjukan bahwa pada penggunaan wireless security protocols WPA2-AES maupun WPA3 - SAE di channel width $20 \mathrm{Mhz}$, throughput mengalami penurunan bila dibandingkan ketika jaringan wireless tidak menerapkan wireless security (No Security), dimana penggunaan WPA2AES dan WPA3-SAE ketika pengujian dengan mengirimkan paket TCP window size dengan ukuran 128 Kbyte dan 384 Kbyte mengalami penurunan throughput sebanyak $1 \mathrm{Mbps}$ atau $0.5 \%$. Throughput mengalami penurunan kembali ketika pengujian
WPA2-AES dan WPA3-SAE menggunakan ukuran TCP window size lebih besar yaitu menggunakan ukuran TCP window size berukuran 640 Kbyte, 1152 Kbyte dan 1408 Kbyte mengalami penurunan sebanyak 2 Mbps atau $0.9 \%$.

Hasil pengujian terlihat di dalam tabel 3.

Tabel 3. Persentase Penurunan Wireless Security Protocol di Channel Width $20 \mathrm{Mhz}$

\begin{tabular}{|c|c|c|c|c|c|}
\hline Wireless & \multicolumn{5}{|c|}{ Ukuran Window Size (KByte ) } \\
\cline { 2 - 6 } $\begin{array}{c}\text { Security } \\
\text { Protocols }\end{array}$ & 128 & $\mathbf{3 8 4}$ & $\mathbf{6 4 0}$ & $\mathbf{1 1 5 2}$ & $\mathbf{1 4 0 8}$ \\
\hline WPA2 - AES & $0.5 \%$ & $0.5 \%$ & $0.9 \%$ & $0.9 \%$ & $0.9 \%$ \\
\hline WPA3 - SAE & $0.5 \%$ & $0.5 \%$ & $0.9 \%$ & $0.9 \%$ & $0.9 \%$ \\
\hline
\end{tabular}

Sumber : (Saputro et al., 2021)

Dari tabel 3, terlihat bahwa untuk channel width 20 Mhz jaringan wireless 802.11ax semakin besar ukuran TCP window Size maka throughput yang didapatkan oleh PC client akan mengalami penurunan semakin besar.

2. Perbandingan Penggunaan Wireless Security Protocol Untuk Channel Width $40 \mathrm{Mhz}$

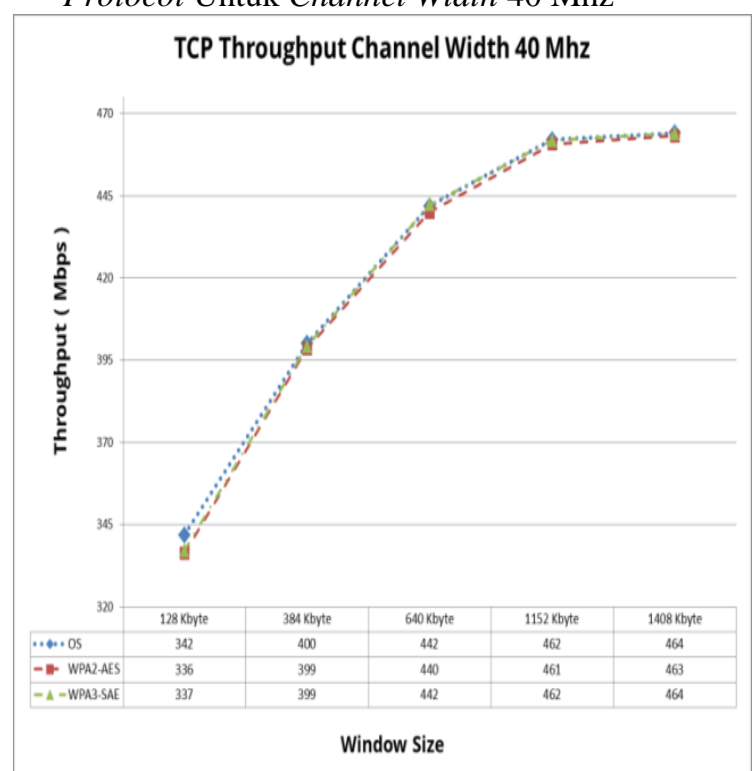

Sumber : (Saputro et al., 2021)

Gambar 7. Grafik Perbandingan Throughput untuk Channel Width $40 \mathrm{Mhz}$

Berdasarkan gambar 7, menunjukan bahwa penggunaan wireless security protocols WPA2-AES dan WPA3 - SAE di channel width $40 \mathrm{Mhz}$, throughput juga mengalami penurunan signifikan. Ketika jaringan wireless menerapkan WPA2-AES dan pengujian menggunakan TCP Window Size dengan ukuran 128 Kbyte, throughput mengalami penurunan sebanyak $6 \mathrm{Mbps}$ atau $1.79 \%$ sedangkan penerapan WPA3-SAE, throughput mengalami penurunan sebanyak $5 \mathrm{Mbps}$ atau $1.48 \%$. Hasil pengujian selanjutnya untuk WPA2-AES ketika menggunakan ukuran TCP window Size 384 Kbyte, 1152 Kbyte dan 1408 Kbyte throughput mengalami 
penurunan sebanyak $1 \mathrm{Mbps}$ atau $0.25 \%$ dan $2 \mathrm{Mbps}$ atau $0.45 \%$ ketika menggunakan ukuran TCP windows size 640 Kbyte. Untuk penggunaan WPA3SAE, troughput mengalami penurunan kembali ketika pengujian menggunakan ukuran TCP window size 384 Kbyte sebanyak 1 Mbps atau 0.25\%, selanjutnya throughput yang di dapatkan PC client tidak mengalami penurunan walaupun menerapkan mode WPA3-SAE ketika pengujian menggunakan ukuran TCP window size 640 Kbyte, 1152 Kbyte dan 1408 Kbyte. Hasil pengujian terlihat di dalam tabel 4.

Tabel 4. Persentase Penurunan Wireless Security Protocol di Channel Width $40 \mathrm{Mhz}$

\begin{tabular}{|c|c|c|c|c|c|}
\hline \multirow{2}{*}{$\begin{array}{c}\text { Wireless } \\
\text { Security } \\
\text { Protocols }\end{array}$} & \multicolumn{5}{|c|}{ Ukuran Window Size ( KByte ) } \\
\cline { 2 - 6 } & $\mathbf{1 2 8}$ & $\mathbf{3 8 4}$ & $\mathbf{6 4 0}$ & $\mathbf{1 1 5 2}$ & $\mathbf{1 4 0 8}$ \\
\hline WPA2 - AES & $1.79 \%$ & $0.25 \%$ & $0.45 \%$ & $0.25 \%$ & $0.25 \%$ \\
\hline WPA3 - SAE & $1.48 \%$ & $0.25 \%$ & $0 \%$ & $0 \%$ & $0 \%$ \\
\hline
\end{tabular}

Sumber : (Saputro et al., 2021)

Dari tabel 4, terlihat bahwa untuk channel width 40 Mhz jaringan wireless 802.11ax penggunaan WPA2AES mengalami presentase penurunan paling signifikan hingga $1.79 \%$ bila dibandingkan dengan WPA3-SAE. Dimana throughput yang di dapatkan PC client ketika menerapkan WPA3-SAE sama seperti ketika tidak menerapkan wireless security (No Security), hal ini ditunjukan ketika pengujian pengiriman paket menggunakan ukuran TCP window size 640 Kbyte, 1152 Kbyte dan 1408 Kbyte.

3. Perbandingan Penggunaan Wireless Security Protocol Untuk Channel Width $80 \mathrm{Mhz}$

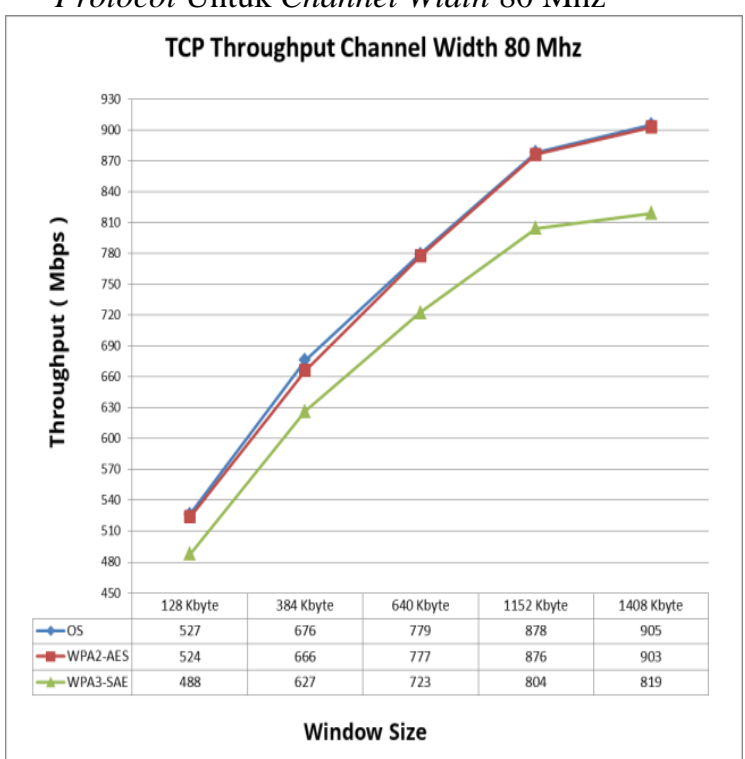

Sumber : (Saputro et al., 2021)

Gambar 8. Grafik Perbandingan Throughput untuk Channel Width $80 \mathrm{Mhz}$

Berdasarkan gambar 8, penerapan wireless security protocol di channel width $80 \mathrm{Mhz}$ menunjukan bahwa penggunaan WPA2-AES menurunkan throughput hingga $1.48 \%$ atau sebanyak $10 \mathrm{Mbps}$ ketika pengujian menggunakan ukuran TCP window size 384 Kbyte, namun ketika pengujian menggunakan ukuran TCP window size lebih besar yaitu 640 Kbyte, 1152 Kbyte dan 1408 Kbyte penurunan throughput lebih sedikit hanya $1-2$ Mbps atau $0.22 \%-0.26 \%$. Berbeda dengan WPA2AES, hasil pengujian untuk WPA3-SAE menunjukan throughput yang didapatkan PC client mengalami penurunan sangat besar hingga $86 \mathrm{Mbps}$ atau $9.50 \%$ ketika pengujian menggunakan ukuran TCP window size 1408 Kbyte. seperti yang ditunjukan di dalam tabel 5.

Tabel 5. Persentase Penurunan Wireless Security Protocol di Channel Width $80 \mathrm{Mhz}$

\begin{tabular}{|c|c|c|c|c|c|}
\hline Wireless & \multicolumn{5}{|c|}{ Ukuran Window Size (Kbyte ) } \\
\cline { 2 - 6 } $\begin{array}{c}\text { Security } \\
\text { Protocols }\end{array}$ & $\mathbf{1 2 8}$ & $\mathbf{3 8 4}$ & $\mathbf{6 4 0}$ & $\mathbf{1 1 5 2}$ & $\mathbf{1 4 0 8}$ \\
\hline WPA2 - AES & $0.57 \%$ & $1.48 \%$ & $0.26 \%$ & $0.23 \%$ & $0.22 \%$ \\
\hline WPA3 - SAE & $7.4 \%$ & $7.25 \%$ & $7.19 \%$ & $8.43 \%$ & $9.50 \%$ \\
\hline
\end{tabular}

Sumber : (Saputro et al., 2021)

Terlihat di dalam tabel 5 menunjukan bahwa penerapan WPA3-SAE di channel width $80 \mathrm{Mhz}$ mengalami penurunan throughput seiring penggunaan ukuran TCP window size yang semakin besar. Hal ini berbeda ketika penggunaan WPA2 AES di channel width $80 \mathrm{Mhz}$ seiring penggunaan ukuran TCP window size yang besar penurunan throughput hanya $1-2$ Mbps atau $0.22 \%-0.26 \%$.

\section{KESIMPULAN}

Berdasarkan hasil pengujian yang telah dilakukan untuk dampak penggunaan wireless security protocol mode Open Security, WPA2 - AES dan WPA3 - SAE dengan variasi penggunaan channel width $20 \mathrm{Mhz}, 40 \mathrm{Mhz}$ dan $80 \mathrm{Mhz}$ pada jaringan wireless 802.11ax maka dapat ditarik kesimpulan bahwa penggunaan wireless security protocol baik WPA2-AES dan WPA3-SAE di dalam jaringan wireless IEEE 802.11ax berdampak pada penurunan kualitas throughput yang didapatkan oleh PC client. Selanjutnya untuk hasil skenario pertama pengujian di channel width $20 \mathrm{Mhz}$ menunjukan bahwa ketika jaringan wireless menggunakan wireless security protocols WPA2-AES dan WPA3-SAE semakin besar ukuran TCP windows size yang dikirimkan, penurunan throughput semakin besar sebanyak $0.9 \%$. dan untuk hasil skenario kedua pengujian di channel width $40 \mathrm{Mhz}$ menunjukan bahwa ketika penggunaan WPA2-AES mengalami presentase penurunan paling signifikan hingga $1.79 \%$ bila dibandingkan dengan WPA3-SAE hanya $1.48 \%$. Namun penggunaan WPA3-SAE di channel width $40 \mathrm{Mhz}$ menunjukan hasil yang baik terlihat semakin 
besar ukuran TCP window size, throughput yang di dapatkan sama seperti penggunaan open security. Sehingga berdasarkan hasil pengujian untuk penggunaan wireless security protocol di channel width $40 \mathrm{Mhz}$ dapat menggunakan mode WPA3SAE kemudian untuk hasil skenario ketiga pengujian di channel width $80 \mathrm{Mhz}$ menunjukan bahwa penggunaan WPA2-AES lebih baik karena hanya mengalami penurunan hingga $1.48 \%$ bila dibandingkan dengan penggunaan WPA3-SAE yang mengalami penurunan signifikan hingga $9.50 \%$. Sehingga berdasarkan hasil pengujian untuk penggunaan wireless security protocol di channel width $80 \mathrm{Mhz}$ dapat menggunakan mode WPA2AES.

Tabel 6. Persentase Penurunan Terbesar Dari Hasil Pengujian

\begin{tabular}{|c|c|c|c|}
\hline \multirow{2}{*}{$\begin{array}{c}\text { Wireless } \\
\text { Security } \\
\text { Protocols }\end{array}$} & \multicolumn{3}{|c|}{ Channel Width } \\
\cline { 2 - 4 } & $\mathbf{2 0} \mathbf{~ M h z}$ & $\mathbf{4 0} \mathbf{~ M h z}$ & $\mathbf{8 0} \mathbf{~ M h z}$ \\
\hline WPA2 - AES & $0.9 \%$ & $1.79 \%$ & $1.48 \%$ \\
\hline WPA3 - SAE & $0.9 \%$ & $1.48 \%$ & $9.50 \%$ \\
\hline
\end{tabular}

Sumber : (Saputro et al., 2021)

\section{REFERENSI}

Bakri, M. A., Farhan, M., \& Sujatmiko, A. (n.d.). Performansi Kinerja Jaringan WLAN $5 \mathrm{GHz}$ Sebagai Alternatif WLAN 2, 4 GHz pada Area Perkantoran. 7(2), 53-58.

Kohlios, C. P., \& Hayajneh, T. (2018). A comprehensive attack flow model and security analysis for $\mathrm{Wi}-\mathrm{Fi}$ and WPA3. Electronics (Switzerland). https://doi.org/10.3390/electronics7110284

Kolahi, S. S., \& Almatrook, A. A. (2017). Impact of security on bandwidth and latency in IEEE 802.11ac client-to-server WLAN. International Conference on Ubiquitous and Future Networks, ICUFN, 893-897. https://doi.org/10.1109/ICUFN.2017.7993928

Kwon, S., \& Choi, H. K. (2021). Evolution of Wi-Fi
Protected Access: Security Challenges. IEEE Consumer Electronics Magazine. https://doi.org/10.1109/MCE.2020.3010778

Lepaja, S., Maraj, A., \& Berzati, S. (2018). Wireless LAN Planning and Performance Analysis. https://doi.org/10.2507/daaam.scibook.2018.2 6

Mohammed, A. T. (2016). Evaluation of WEP, WPA and WPA2 Security Protocols on 802. llac Client to Server WLAN Performance. 9, $1-13$.

Riyan Feraldi., 2019. (2019). Kelemahan Keamanan Jaringan Wireless. Journal of Chemical Information and Modeling.

Saputro, V. A., Raharjo, S., \& Pramono, E. (2021). Pengaruh Wireless Security Protocol Pada Throughput Jaringan Wireless 802.11ax. 23(2), 1-7.

Sun, S. (2019). A Chosen Random Value Attack on WPA3 SAE authentication protocol. Cryptology EPrint Archive.

Supriyanto, A. (2006). Analisis Kelemahan Keamanan pada Jaringan Wireless. Analisis Keamanan Jaringan Wireless.

Tsetse, A., Bonniord, E., Appiah-Kubi, P., \& Tweneboah-Kodua, S. (2018). Performance Study of the Impact of Security on 802.11ac Networks. Advances in Intelligent Systems and Computing, 738, 11-17. https://doi.org/10.1007/978-3-319-77028-4_3

\section{PROFIL PENULIS}

Vian Ardiyansyah Saputro, Lahir di Kota Pemalang, 29 Maret 1990, Alumni D4 Teknik Telekomunikasi Politeknik Negeri Semarang dan saat ini sedang menempuh pendidikan Magister Teknik Informatika di Universitas AMIKOM Yogyakarta. Saat ini saya bekerja sebagai Senior IT Infrastruktur dna Support di salah satu perusahaan FCMG di Karawang. Silahkan Anda juga dapat mengunjungi website pribadi saya di www.acavicomputech.com 